\title{
KARAKTERISASI DAERAH RAWAN GERAKAN TANAH DI LAPANGAN PANDANMURTI DESA CANDIGARON KECAMATAN SUMOWONO KABUPATEN SEMARANG DENGAN METODE MIKROTREMOR
}

\section{LANDSLIDE ZONE CHARACTERIZATION IN PANDANMURTI FIELD CANDIGARON VILLAGE, SUMOWONO SUBDISTRICT, SEMARANG REGENCY BY USING MICROTREMOR METHOD}

Dwi P. Sasongko', Gatot Yuliyanto², Arifin Zaenal ${ }^{3}$

1,2,3 Departemen Fisika Universitas Diponegoro

Info Artikel:

- Artikel Masuk: 8 November 2019

\begin{abstract}
ABSTRAK
Gerakan tanah di Lapangan Pandanmurti, Desa Candigaron, Kecamatan Sumowono, Kabupaten Semarang berupa tanah retak dan sebagian mengalami penurunan tanah. Untuk mengindentifikasi daerah Gerakan tanah di lokasi penelitian ini dilakukan survei mikrotemor dengan metode HVSR. Berdasarkan pemodelan 2D daerah yang mengalami Gerakan tanah terkarakterisasi oleh lapisan tanah dengan nilai amplifikasi lebih besar daripada 1 dengan rentang amplifikasi 1-6,5 Frekusensi dominan lapisan tanah lokasi penelitian terkarakterisasi mempunyai nilai 0,02-0,06 $\mathrm{Hz}$. Berdasarkan pemodelan 3D separasi berkas amblesan dengan bagian yang belum ambles dicirikan dengan adanya dikontinuitas di bagian selatan-tenggara dengan isovalue nilai frekuensi $1,36 \mathrm{~Hz}$ dan daerah yang tidak mengalami deformasi lebih lanjut dicirikan dengan isovalue nilai amplifikasi lebih besar dari 0,79. Berdasarkan kontur lokasi penelitian Gerakan tanah di lokasi penelitian bersifat rayapan (creeping). Pengukuran lebih lanjut menuju daerah terlewati atau pilihannya untuk mitigasi bencana longsor lanjutan.
\end{abstract}

Kata Kunci: Gerakan tanah, HSVR, Frekuensi, Amplifikasi, Deformasi

\begin{abstract}
The ground movement in Pandanmurti Field, Candigaron Village, Sumowono Subdistrict, Semarang Regency is in the form of cracked land and some of it has land subsidence. To identify the area of ground movement in the study site, a microtremor survey was conducted using the HVSR method. Based on 2D modeling areas that experience soil movement are characterized by a layer of soil with amplification values greater than 1 with an amplification range of 1-6.5. The dominant frequency of soil layers characterized by research sites has a value of 0.02-0.6 Hz. Based on 3D modeling the separation of the former subsidence with the part that has not subsided is characterized by the discontinuity in the south-southeast with isovalue $1.36 \mathrm{~Hz}$ frequency values and areas that do not undergo further deformation are characterized by isovalue amplification values greater than 0.79. Based on the contour of the land movement research location at the research site is creeping. Further measurements towards the skipped areas or their options for mitigating further landslides disaster.
\end{abstract}

Keyword: Ground motion, HVSR, Frequency, Amplification, Deformation

\section{PENDAHULUAN}

Gerakan tanah adalah suatu peristiwa geologi yang terjadi karena pergerakan masa berbagai tipe dan jenis batuan atau tanah akibat gaya berat. Secara umum kejadian gerakan tanah disebabkan oleh kondisi material dan faktor eksternal yang menyebabkan bergeraknya material tersebut. Selain gravitasi yang 
memengaruhi suatu lereng yang curam, faktor-faktor lainnya yang turut berpengaruh antara lain kondisi lereng dari bebatuan dan tanah yang diperlemah oleh saturasi air yang diakibatkan hujan lebat serta getaran kuat yang menyebabkan tekanan pada partikel-partikel mineral dan bidang lemah pada massa batuan dan tanah. Fenomena pergerakan tanah bisa terjadi di darah dataran yang memiliki kemiringan landai dengan kondisi tanah yang karakteristiknya kedap air seperti tanah lempung atau batuan, sedangkan fenomena pergerakan tanah pada dareah dengan kemiringan yang curam seperti tebing akan menyebabkan longsoran yang bersifat luncuran. Menurut Sassa dan Canuti (2009) gerakan tanah merupakan fenomena alam yang kompleks dalam mencari keseimbangan baru akibat adanya gangguan yang mempengaruhi dan menyebabkan terjadinya pengurangan kuat geser serta peningkatan tegangan geser tanah.

Tanah retak hingga amblas hingga sedalam lebih dari dua meter terjadi di Dusun Delik Desa Candi Garon, Kecamatan Sumowono, Kabupaten Semarang, Jawa Tengah. Pusat retakan berada Dusun Delik tepatnya di Lapangan Pandan Murti (Gambar 1). Awal rekahan terjadi rabu tanggal 22 Februari 2017 dan saat itu penurunan hanya sedalam 30 sentimeter saja dan tetapi karena intensitas hujan yang tinggi, rekahan tersebut memanjang hingga masuk ke permukiman warga dan mengakibatkan jalan utama penghubung Desa Candi Garon dan Desa Kemitir putus. Hingga tanggal 2 maret 2017 fenomena tanah bergerak tersebut menyebabkan amblesnya tanah sepanjang puluhan meter dengan kedalaman 1,5meter hingga 2 meter. Secara historis lapangan tersebut sebelumnya memang sebuah lereng dan ada rumah-rumah warga namun dulu karena pernah retak akhirnya warga pindah dan kemudian dijadikan lapangan.

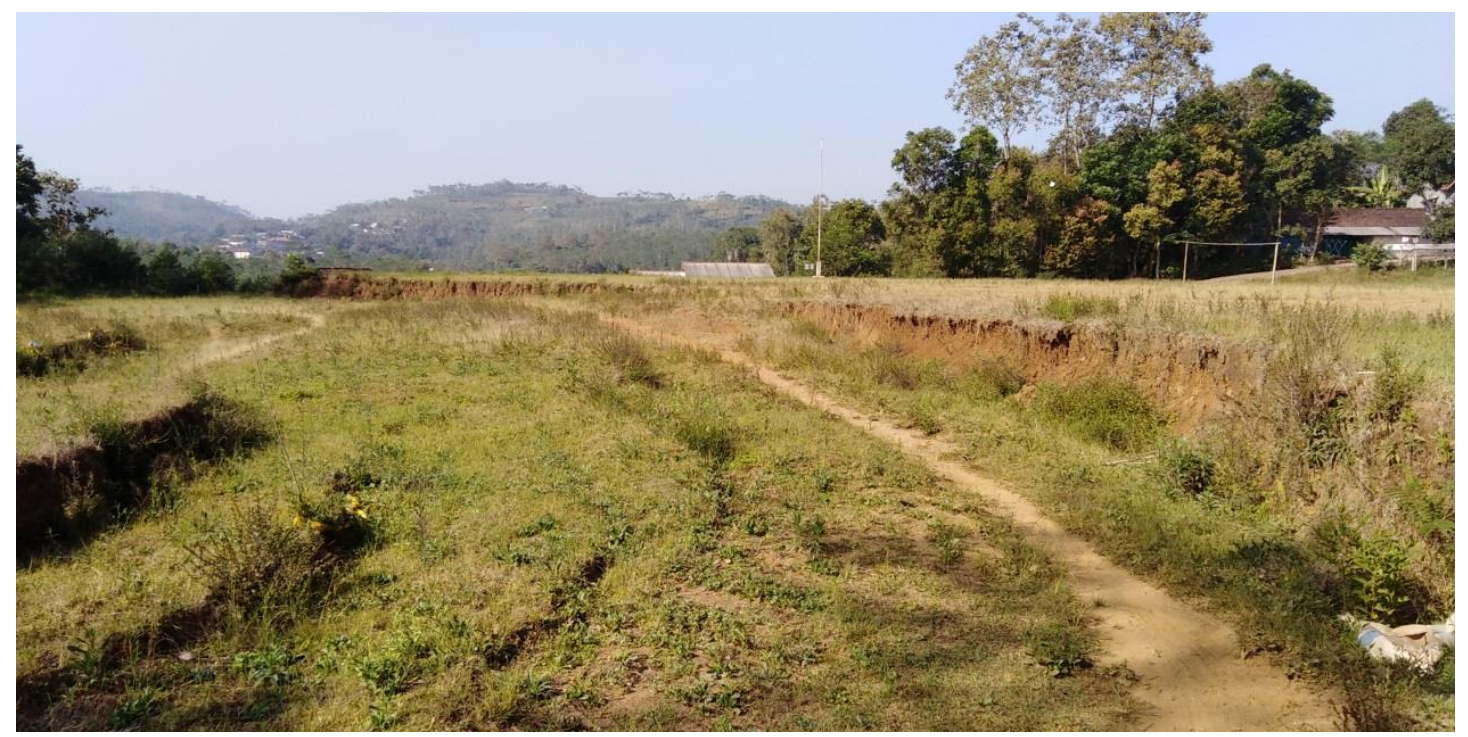

Gambar 1 Lapangan Pandanmurti di Desa Candigaron, Sumowono, Kabupaten Semarang yang mengalami fenomena gerakan tanah seperti terbelah

Beberapa metode geofisika telah banyak digunakan untuk penyelidikan kestabilan lereng, kelongsoran, serta menetapkan ketidak homogenan material, batas dan sifat dari material (Hack, 2000). Teknik ini memungkinkan studi tentang variasi spasial dan temporal struktur geologi. Menurut Jongmans dan Garambois (2007) kelebihan dari penerapan metode geofisika dalam penyelidikan kestabilan lereng dan longsoran adalah faktor fleksibilitas, relatif cepat dan mudah diterapkan, tidak merusak dan dapat memberikan informasi struktur internal dari tanah atau massa batuan, serta memungkinkan dalam penyelidikan skala (volume) besar. Konsep dasar dari penerapan metode geofisika untuk penyelidikan kelongsoran lereng adalah akibat adanya perubahan parameter fisis tanah yang umumnya memberikan kekontrasan yang cukup besar dengan tanah sekitarnya (Whiteley, 2004).

Salah satu metode geofisika untuk mengidentifikasi daerah rawan gerakan tanah adalah metode mikrotremor. Yuliyanto dkk $(2016,2017,2018)$ mengaplikasikan metode mikrotremor dan melakukan inversi $\mathrm{H} / \mathrm{V}$ berdasarkan algoritma yang diusulkan oleh Herak (2009) untuk mendapatkan distribusi kecepatan 
gelombang sekunder di lokasi daerah longsoran untuk mengidentifikasi bidang gelincir daerah rawan gerakan tanah dan memetakan nilai ground shear strain daerah rawan longsor di Wirogomo, Kecamatan Banyubiru, Kabupaten Semarang dan di Jabungan, Kecamatan banyumanik, Kota Semarang. Menurut Ammosov dkk (2007) zona anomali daerah rawan gerakan tanah yaitu daerah yang diindikasikan akan terjadi longsor dapat ditentukan dengan faktor amplikasi yang tinggi dan berkorelasi dengan kepadatan tanah yang berkurang atau kecepatan gelombang S permukaan yang rendah. Menurut Mirzaoglu dan Dykmen (2003) survei mikrotremor dapat digunakan untuk mengetahui karakteristik lapisan tanah berdasarkan frekuensi dominan dan faktor amplifikasinya. Untuk itu pada makalah ini dilakukan karakterisasi fenomena daerah rawan gerakan tanah di Desa Candigaron, Kecamatan Sumowono, Kabupaten Semarang berdasarkan faktor amplifikasi dan frekuensi yang bersesuaian.

\section{DATA DAN METODE}

\subsection{Mikrotremor}

Mikrotremor adalah getaran alami yang merambat dalam lapisan tanah dan bersifat kontinu dengan amplitudo rendah, dapat ditimbulkan oleh peristiwa alam ataupun buatan, seperti angin, gelombang laut ataupun getaran kendaraan (Arai dan Tokimatsu, 2005). Mikrotremor memiliki amplitudo 0,1-1 mikron dan kecepatan 0,001-0,01 cm/s. Berdasarkan periodenya mikrotremor dapat diklasifikasikan menjadi mikroremor periode pendek untuk getaran dengan periode yang kurang dari 1 detik dan periode panjang untuk getaran yang periodenya lebih dari 1 detik. Perioda besar berhubungan dengan struktur tanah yang lebih dalam dan menunjukkan dasar dari batuan keras.

Metode HVSR merupakan metode yang tersedia untuk pengolahan data mikrotremor dengan membandingkan komponen horizontal sinyal mikrotremor terhadap komponen vertikal yang dapat dituliskan sebagai:

$$
H V S R=\frac{\sqrt{\left(S_{N S}\right)^{2}+\left(S_{E W}\right)^{2}}}{\left(S_{V}\right)^{2}}
$$

dengan $S_{N S}$ adalah nilai amplitudo spektrum komponen utara-selatan, $S_{E W}$ nilai amplitudo spektrum komponen timur-barat, dan $S_{V}$ adalah nilai amplitudo spektrum komponen vertikal. Hasil pengolahan dari metode ini adalah kurva $\mathrm{H} / \mathrm{V}$ yang puncaknya menunjukkan informasi tapak lokal (site effect) berupa nilai frekuensi dominan getaran tanah dan faktor amplifikasi dari gelombang yang terekam dalam tanah (Nakamura, 1989). Site effect terjadi karena adanya lapisan tanah lunak yang terletak di atas batuan dasar.

\subsection{Frekuensi dominan dan Amplifikasi}

Frekuensi dominan adalah nilai frekuensi yang sering muncul sehingga disebut sebagai nilai frekuensi alami pada suatu wilayah pengukuran dapat menunjukkan jenis dan karakteristik lapisan tanah atau batuan pada wilayah tersebut.

Lapisan lapuk atau sedimen tersusun atas material berukuran halus (lanau-lempung) yang belum terkonsolidasi baik (Fah dkk., 2001). Material tersebut dianggap sangat baik menyerap air namun tidak dapat mendistribusikannya dengan baik. Material yang sangat rentan terhadap getaran ini dapat mengalami longsor ketika volumenya bertambah akibat terserapnya air sehingga menimbulkan gerakan material secara massal. Daerah dengan lapisan lapuk yang tebal memiliki tingkat bahaya yang lebih tinggi terhadap bencana tanah longsor karena volume lapisan lapuk yang berisi material halus mudah mengalami deformasi atau perpindahan massa.

Faktor amplifikasi merupakan perbesaran gelombang seismik yang terjadi akibat adanya perbedaan yang signifikan antar lapisan. Gelombang seismik akan mengalami perbesaran apabila merambat pada suatu medium yang lebih lunak dibandingkan medium awal yang dilaluinya. Semakin besar kontras parameter perambatan gelombang (densitas dan kecepatan) pada kedua lapisan tersebut, maka nilai amplifikasi akan semakin tinggi (Nakamura, 2000). Nilai faktor amplifikasi dapat bertambah apabila lapisan tanah atau batuan telah mengalami deformasi (pelapukan, pelipatan, dan pesesaran) yang mengubah sifat batuan. Pada 
Sasongko, Yuliyanto, Zaenal/ Jurnal Pembangunan Wilayah dan Kota, Vol. 16, No.2, 2020, 136-143 Doi: https://doi.org/10.14710/pwk.v16i2.26401

batuan yang sama, nilai amplifikasi dapat bervariasi sesuai dengan tingkat deformasi pada pelapukan tubuh batuan tersebut. Berdasarkan pengertian tersebut, maka amplifikasi dapat dituliskan dalam persamaan (Nakamura, 1997).

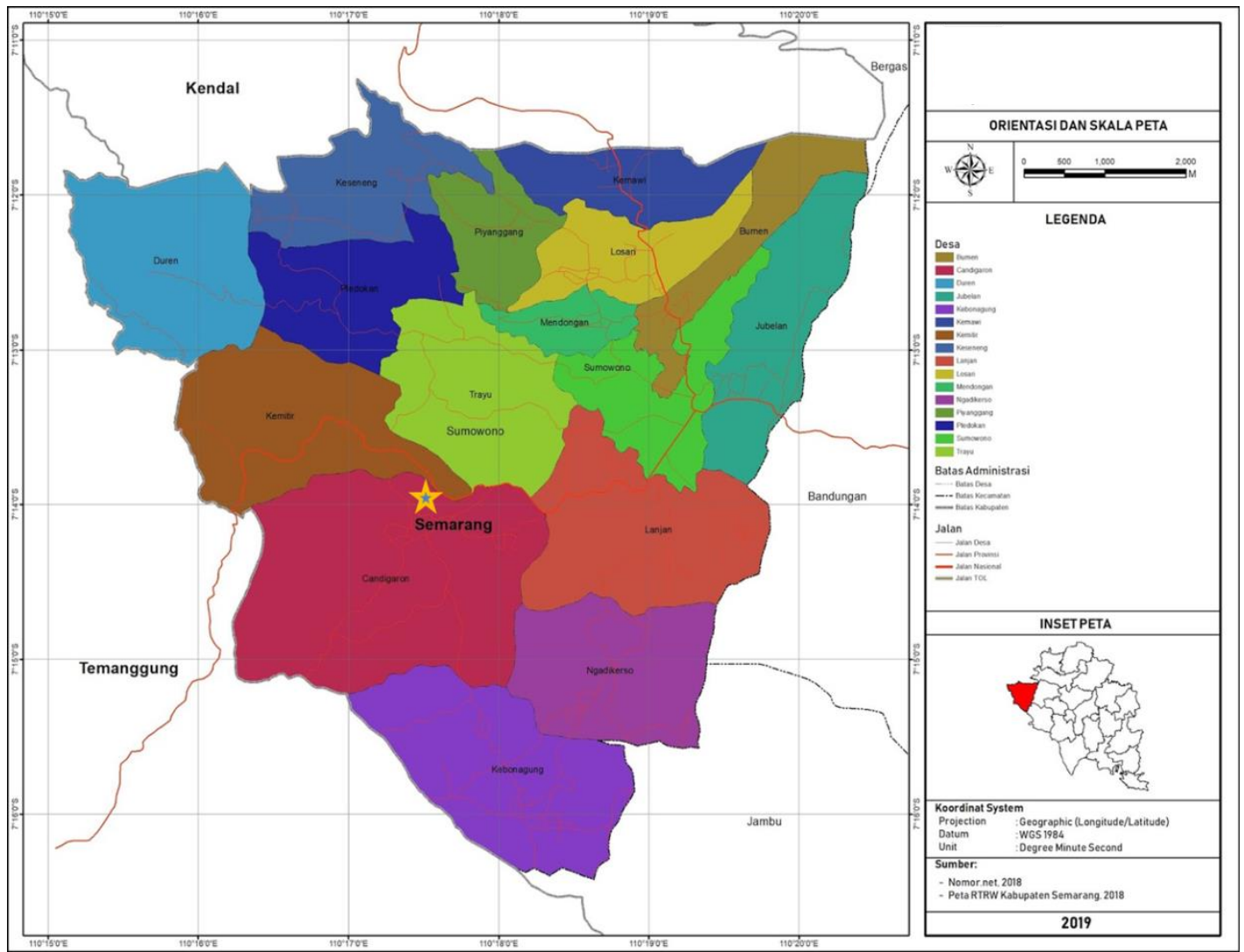

Gambar 2 Peta administrasi Kecamatan Sumowono. Daerah penelitian yaitu Lapangan Pandanmurti Desa Candigaron ditandai dengan lambang bintang berwarna kuning

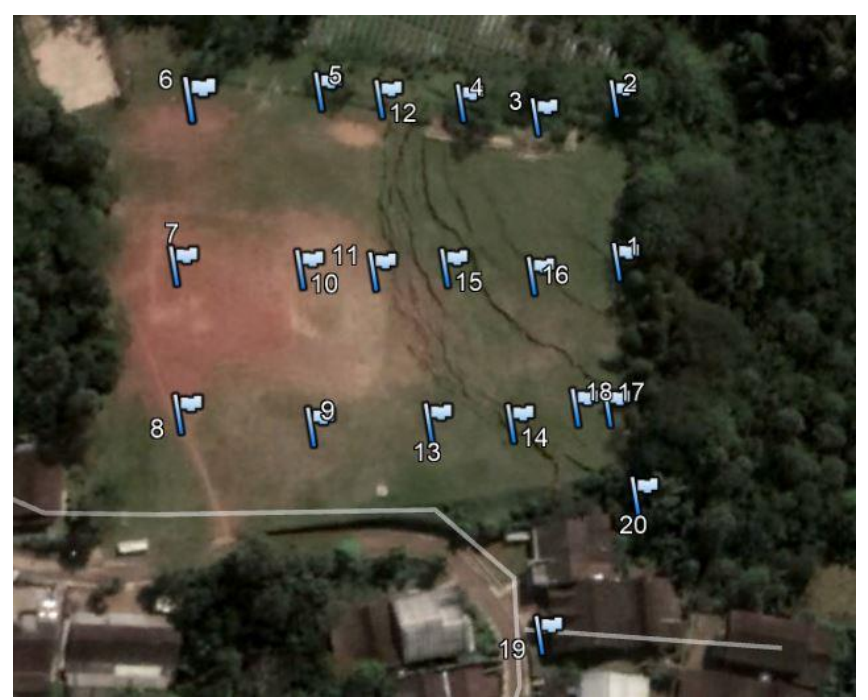

Gambar 3. Lokasi Pengambilan Data Mikrotremor 


\subsection{Survei mikrotremor}

Lokasi penelitian secara adminitratif diberikan pada Gambar 2 dan lokasi akusisi data mikrotremor diberikan pada Gambar 3 yang terdiri dari 20 titik pengukuran dengan 3 lintasan yang memotong Lapangan Pandanmurti Desa Candigaron dengan arah barat-timur. Titik 20 terletak di bekas longsoran di belakang rumah penduduk. Data mikrotremor dalam domain waktu kemudian diolah menggunakan Geopsy 2.10.1 untuk mendapatkan kurva-kurva HVSR, kemudian dilakukan karakterisasi sensitivitas secara 2D untuk nilai amplifikasi terhadap frekuensi untuk beberapa lintasan dan kemudian pemodelan 3D dilakukan untuk nilai frekuensi dan nilai amplifikasi tertentu menggunakan Voxler ver 4.

\section{HASIL DAN PEMBAHASAN}

Data frekuensi yang diperoleh kemudian diolah dan dbuat profiling 2D untuk mengetahui sensitivitas nilai amplifikasi terhadap frekuensi dari hasil pengolahan data mikrotremor di lapangan Pandanmurti Desa Candigaron Sumowono untuk lintasan Titik 6- Titik 2 diberikan pada Gambar 4, lintasan Titik 7- Titik 1 diberikan pada Gambar 5, dan lintasan Titik 8-Titik 17 diberikan pada Gambar 6. Hasil pemodelan 3D diberikan pada Gambar 7 dan Gambar 8. Berdasarkan Gambar 3 dan Gambar 4 terlihat antara Titik 5 hingga Titik 2 yang mengalami gerakan tanah mempunyai amplifikasi dalam rentang 1 hingga 1,55 pada frekuensi 0,02-0,6 Hz. Pada Gambar 5 gerakan tanah mempunyai terkarakterisasi mempunyai amplifikasi 1 hingga 6,5 pada frekuensi $0,02-0,6 \mathrm{~Hz}$, dan pada Gambar 6 gerakan tanah terkarakterisasi mempunyai amplifikasi 1-2,1 dengan frekuensi 0,02-0,6 Hz.

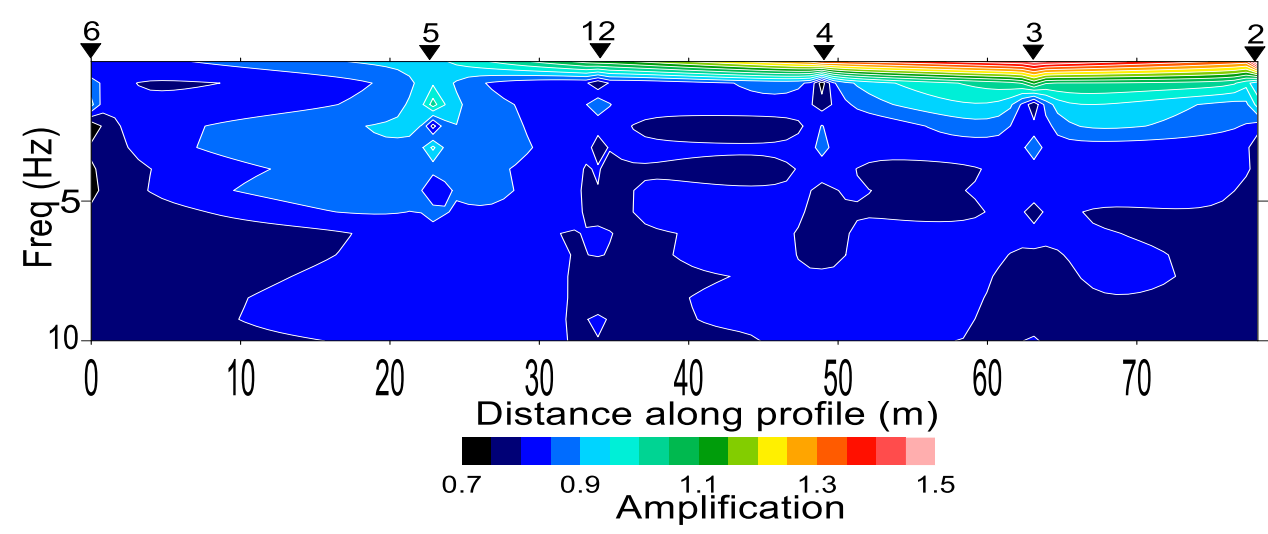

Gambar 4. Profil sensitivitas amplifikasi terhadap frekuensi lintasan antara Titik 6 hingga Titik 2

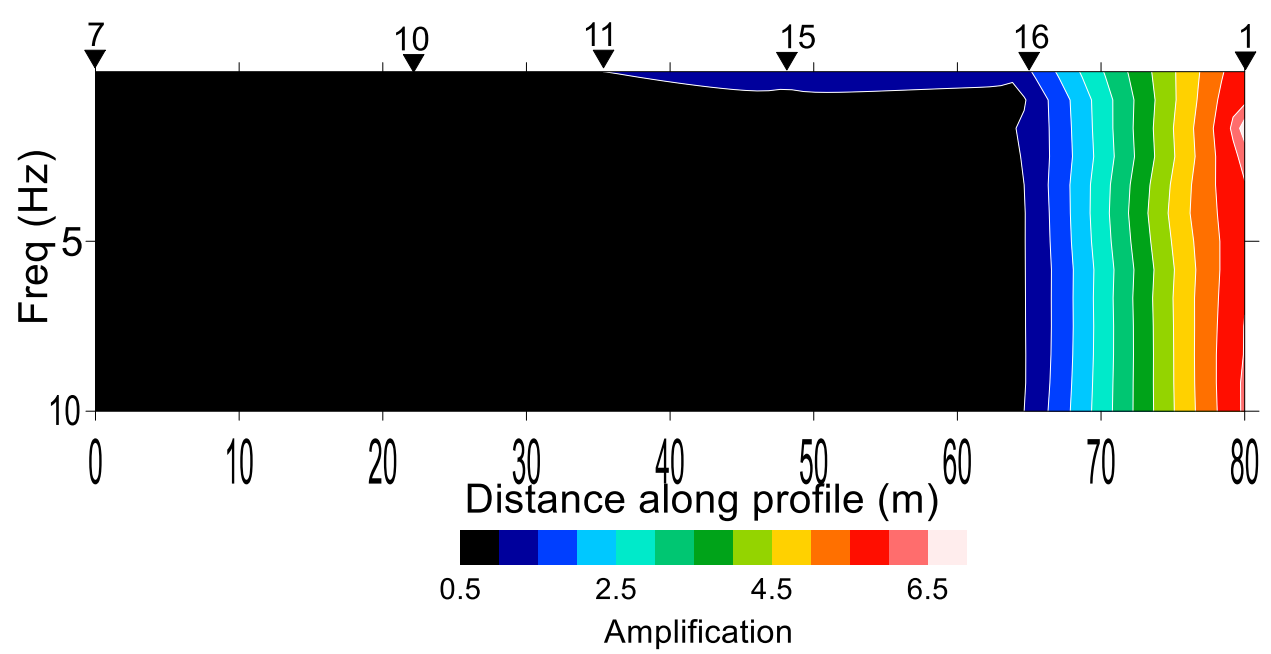

Gambar 5. Profil sensitivitas amplifikasi terhadap frekuensi lintasan antara Titik 7 hingga Titik 1 
Sasongko, Yuliyanto, Zaenal/ Jurnal Pembangunan Wilayah dan Kota, Vol. 16, No.2, 2020, 136-143 Doi: https://doi.org/10.14710/pwk.v16i2.26401

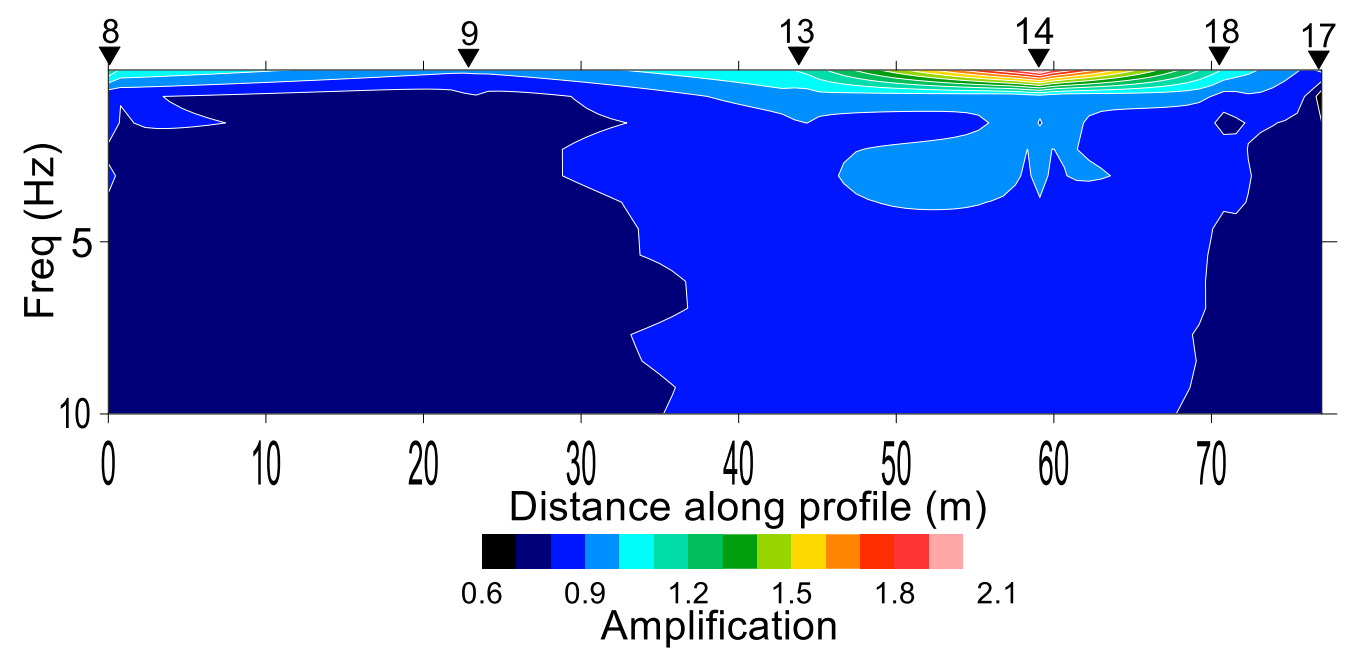

Gambar 6. Profil sensitivitas amplifikasi terhadap frekuensi lintasan antara Titik 8 hingga Titik 17

Berdasarkan pemodelan 3D untuk isovalue nilai frekuensi dominan pada lapisan tanah di daerah penelitian pada Gambar 7 dengan Titik 19 pada gambar 3 sebagai batas bawah dan Titik 20 sebagai batas paling kanan terlihat adanya diskontinuitas yang memisahkan Titik 19 dan Titik 20 dengan titik-titik lainnya. Secara historis lokasi kedua titik ini merupakan bekas zona amblesan di bagian selatan-tenggara Lapangan Pandamurti. Hasil karakterisasi gerakan tanah di lokasi penelitian ini sesuai dengan yang dikemukakan oleh Ammosov dkk (2007) bahwa zona anomali daerah rawan gerakan tanah mempunyai faktor amplikasi yang tinggi.

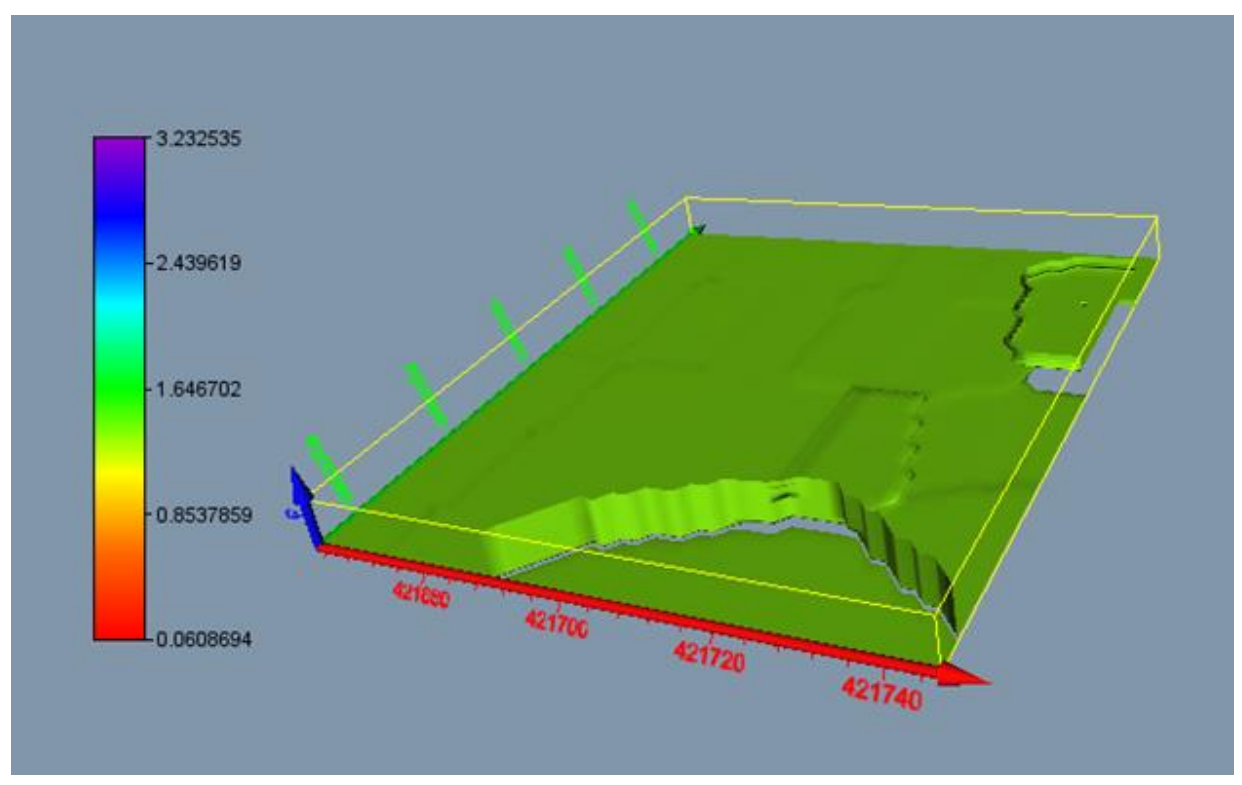

Gambar 7. Pemodelan 3D lokasi penelitian pada isovalue frekuensi 1,36 Hz 


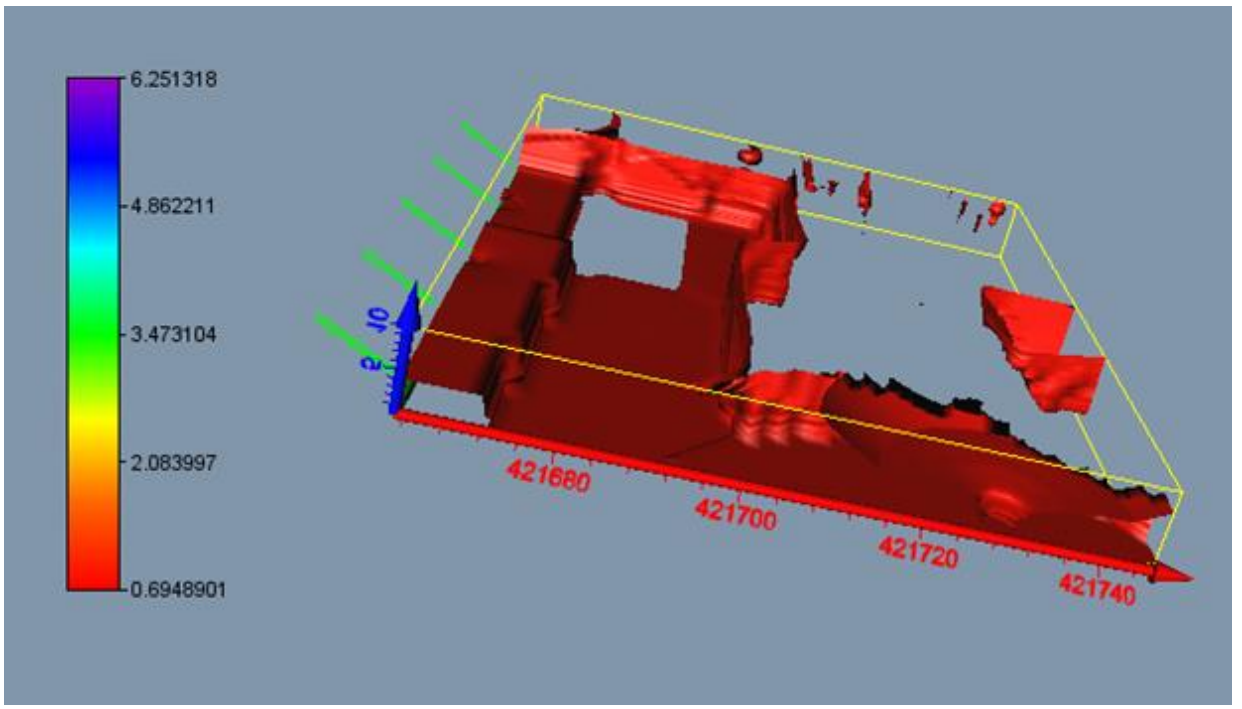

Gambar 8 Pemodelan 3D lokasi penelitian untuk isovalue nilai amplifikasi tanah 0,79

Hujan yang terus menerus mengguyur suatu wilayah dengan kondisi geologi tertentu bisa membuat muka air tanah naik dan membuat kekuatan tanah dalam menyangga permukaan tanah berkurang sehingga terjadi pergerakan tanah. Kondisi pergerakan tanah yang menghasilkan kondisi tanah dengan sebagian mengalami subsidence sehingga seperti terbelah seperti di Lapangan Pandanmurti Dusun Delik Desa Candigaron bukan disebabkan oleh kejenuhan air tanah. Gerakan tanah yang diakibatkan oleh kejenuhan air cenderung longsoran luncuran, sedangkan pergerakan tanah yang terbelah seperti di Lapangan pandamurti tersebut pada dari tengah Februari 2017 hingga awal Maret 2017 tersebut yang menimbulkan kerusakan pada bangunan dan jalan lebih disebabkan adanya kenaikan muka air tanah secara perlahan dalam waktu yang cukup lama (creeping). Resapan air hujan yang mencapai lapisan lempung kedap air akan mengalami kontak dengan lapisan lempung, air mengalir di atas lapisan lempung dan menyebabkan hancurnya lapisan lempung sehingga menjadi licin yang kemudian menjadi bidang gelincir.

\section{KESIMPULAN}

Berdasarkan pemodelan 2D daerah yang mengalami gerakan tanah di Lapangan Pandanmurti Desa Candigaron, Kecamatan Sumowono, Kabupaten Semarang terkarakterisasi oleh lapisan tanah dengan frekuensi dominan 0,02-0,6 Hz dan amplifikasi lebih besar daripada 1 yang secara spesifik di lokasi penelitian ini mempunyai rentang amplifikasi $1-6,5$. Untuk pemodelan 3D bekas amblesan dicirikan dengan adanya diskontinuitas di bagian selatan-tenggara mempunyai frekuensi $1,36 \mathrm{~Hz}$ dan daerah yang tidak mengalami deformasi lebih lanjut dicirikan dengan isovalue nilai amplifikasi lebih besar dari 0,79. Gerakan tanah di lokasi penelitian bersifat rayapan (creeping). Pengukuran lebih lanjut menuju daerah terlewati atau pilihannya untuk mitigasi bencana longsor lanjutan.

\section{PERNYATAAN RESMI}

Penelitian ini didanai dengan dana selain APBN Fakultas Sains dan Matematika Undip Tahun 2019.

\section{DAFTAR PUSTAKA}

Ammosov, A., A. Kalinina, V. Volkov. 2007. Using a three-component KMV seismometer for recording microtremors in the zone of a landslide slope, Seismic Instruments, Vol. 43, No. 1., pp. 26-33.

Arai, H. and K. Tokimatsu. 2005. S-wave Velocity Profiling by Joint Inversion of Microtremor Dispersion Curve and Horizontal-to-Vertical (H/V) Spectrum. Bulletin of the Seismological Society of America Vol. 95 No. 5. 
Fah, D., K. Fortunat, and G. Domenico. 2001. A Theoretical Investigation of Average H/V Ratios. Geophys. J. Int. (2001) 145, 535-549.

Hack, R., 2000. Geophysics for slope stability, Surveys in Geophysics, vol. 21, p. 423-448.

Hayashi, H., Ling, S., Kondo, T.a, 2008, S-wave velocity structure estimated by the microtremor survey method, ISRM International Symposium - 5th Asian Rock Mechanics Symposium 2008, ARMS 2008 Pages 307-314

Jongmans, D. and S. Garambois., 2007. Geophysical investigation of landslides: A review, Bulletin Société Géologique de France 178, 2, p.101-112.

Mirzaoglu, M. and U. Dykmen. 2003. Application of Microtremors to Seismic Microzoning Procedure. Journal of The Balkan Geophysical Society Vol. 6.

Nakamura, Y. 1989. A Method for Dynamic Characteristics Estimation of Subsurface using Microtremor on Ground Surface. Quarterly Report of Railwat Technical Research Institute (RTRI) Vol. 30 No. 1.

Nakamura, Y. 1997. Seismic Vulnerbility Indices for Ground and Structures using Microtremor. World Congress on Railway Research, Japan.

Nakamura, Y. 2000. Clear Identification of Fundamental Idea of Nakamura's Technique and Its Applications. System and Data Research, Japan.

Sassa, K. and P. Canuti. 2009. Landslides Disaster Risk Reduction. Springer-Verlag, Berlin Heidelberg, (Eds.). 19-20p.

Yuliyanto, G., U. Harmoko, and S. Widada, 2016, Identification of Potential Ground Motion Using the HVSR Ground Shear Strain Approach in Wirogomo Area, Banyubiru Subdistrict, Semarang Regency, International Journal of Applied Environmental Sciences, Vol 11, Number 6, pp. 1497-1507

Yuliyanto, G., U. Harmoko, and S. Widada, 2017, Identify the slip surface of land slide in Wirogomo Banyubiru Semarang Regency using HVSR method, International Journal of Applied Environmental Sciences, Vol 12, Number 12, pp. 2069-2078

Yuliyanto, G., U. Harmoko, and RD. Indriana, 2018, Identification of landslide area in Jabungan Village, Banyumanik, Semarang Regency by using microtremor method, International Journal of Recent Trends in Engineering and Research, Vol 04, Issue 05, pp. 129-137

Whiteley, R J., 2004. Application of advanced geophysical technologies to landslides and unstable slopes, Proceedings ISC-2 on Geotechnical and Geophysical Site Characterization, Viana da Fonseca \& Mayne (eds.) 